\title{
Best Practices and Constraints in Geopark Management: Comparative Analysis of Two Spanish UNESCO Global Geoparks
}

\author{
Thais S. Canesin ${ }^{1}$ (D) - José Brilha ${ }^{1}$ • Enrique Díaz-Martínez ${ }^{2}$ \\ Received: 5 December 2018 / Accepted: 7 January 2020 \\ (C) The European Association for Conservation of the Geological Heritage 2020
}

\begin{abstract}
Spain is an international reference for geoparks and geoconservation polices, and it is the second country in the world with the highest number of UNESCO Global Geoparks (UGGps), after China. Additionally, Spain was one of the four countries involved in the establishment of the European Geoparks Network (EGN) in 2000, the first geoparks network. Based on this prominent role of Spain, the present research had the aim to analyse and characterize the process of establishment, development, and management of two Spanish UGGps. This study also intended to identify important aspects of the operation and management that can be a reference to other geoparks. As geological heritage is one of the essential requirements of any geopark, geoconservation has particular importance in the geopark management, requiring experts in the geopark staff. Equally important is that the management structure can effectively ensure an integrated development of the territory, connecting the geopark staff, the whole community, and the stakeholders. A good cooperation of the management team with the administration of protected areas that might exist within a geopark is also noteworthy, because park managers have extensive experience in the implementation of nature conservation and environmental education actions, activities that can certainly benefit any geopark.
\end{abstract}

Keywords Geoconservation · Geological heritage · Geoparks management · UNESCO Global Geoparks

\section{Introduction}

The official label of UNESCO Global Geopark (UGGp) was created in 2015, under the scope of the International Geoscience and Geoparks Programme (IGGP). This programme strengths the geopark concept and raises the attention of the society to the importance of these territories with geological heritage of international significance (McKeever 2015). UGGps are strategic tools for territorial development with medium- to long-term results (Henriques and Brilha 2017). As the number of aspiring geoparks is growing very

This article is part of the Topical Collection on Geoheritage and Conservation: Modern Approaches and Applications Towards the 2030 Agenda, IX ProGEO Symposium, Poland, 25-28th June, 2018

Thais S. Canesin

thaissiqueirac@yahoo.com.br

1 Institute of Earth Sciences, Pole of the University of Minho, Campus of Gualtar, 4710-057 Braga, Portugal

2 Geological Survey of Spain (IGME), Ríos Rosas 23, 28003 Madrid, Spain fast, the management of geoparks is gaining increasing relevance for the success of these initiatives.

Spain is an international reference in geoparks and geoconservation. In 2000, together with Germany, Greece, and France, Spain created the first geoparks network in the world, the European Geoparks Network (EGN) (Zouros 2004), which derive from the Global Geopark Network (GGN). It is the first country in Europe and the second in the world, after China, with the highest number of geoparks (12) (UNESCO 2018). Spain has also a research department on geoheritage in the Geological Survey of Spain (IGME), national laws supporting geoconservation (Laws 5/2007, 42/ 2007, 45/2007, and 33/2015), and regional legislation in some autonomous communities (Díaz-Martínez et al. 2014).

Las Loras UNESCO Global Geopark (LLG) started its activity in 2004/2005 and was accepted as an UGGp in 2017. This geopark is located in the centre-north region of Spain, in the Castilla and León Autonomous Community, and has an area of $950 \mathrm{~km}^{2}$ (ROA 2015; UNESCO 2018).

Comarca de Molina de Aragón-Alto Tajo UNESCO Global Geopark (MATG) has started as a partnership between Molina de Aragón Museum and Alto Tajo Natural Park (ATNP). After 8 years, in 2014, it was accepted in the Global Geopark 
Network (GGN) (Martínez et al. 2011). MATG is located in the east-central region of Spain, in the Castilla-La Mancha Autonomous Community. With a surface of nearly $4000 \mathrm{~km}^{2}$, this geopark is approximately four times larger than LLG (ROA 2012).

The aim of this research is to analyse and characterize the process of implementation, development and management in both geoparks as they have different historical contexts (Canesin 2017). In this study we also intended to underline important aspects of operation and management of geoparks that may serve as a best-practice reference for other geoparks.

\section{Methods}

The selection of the two geoparks for this research (LLG and MATG) was done with the support of the Geological Survey of Spain (IGME), which is a member of the Spanish Committee of UNESCO Global Geoparks. The selection of these two geoparks justified by the fact that they have been established in different ways and they also have different experiences as GGN members.

The data concerning both geoparks was collected from different documents, such as the geoparks' application reports, geological and touristic guides, and other general reports. Information was also provided by the geopark staff.

Field work was done in fifteen of the most representative sites of each geopark in order to evaluate their characteristics and management status. These sites were selected by the geologists of the geoparks. Of these fifteen geological sites, five were chosen according to their scientific value, five for their educational value, and five for their potential touristic use. In addition, geological itineraries, museums, interpretive centres, and tourist information centres were also included in this study.

The research was focused essentially on the geoparks management: general organization, strategies and actions towards geoconservation, education, and tourism (Fig. 1). The general organization was evaluated by its type and structure, management and action plans, staff, and financial sources. Following the recommendations of Brilha (2016) regarding geoconservation, (a) geological inventories, (b) geoconservation legislation and its application, and (c) conservation, interpretation, and monitoring of geological sites were all characterized. Concerning education, the educational programmes for schools and other educational resources were analysed, including interpretive centres, museums, routes, and guided tours. In what concerns tourism, stakeholder partnerships, tourist information centres, and the type of tourist interest of the territory were also characterized. In addition, the existence and type of incentives for the development of scientific activities inside the geoparks were also analysed.
The public database of the Spanish Inventory of Geological Sites (IELIG) was used to characterize the scientific value of the studied geological sites (IELIG 2018).

The history of how the geopark has started, geological and biological setting, and cultural heritage were also considered in order to understand the whole context of sustainable development in both geoparks. All these subjects provided a good general overview of the entire context in which the geopark is inserted and its structure (Fig. 1).

\section{Las Loras UNESCO Global Geopark}

Las Loras UGGp (LLG) has an area of $950 \mathrm{~km}^{2}$ and is located in the centre-north region of Spain, in the Castilla and León Autonomous Community, extending across Burgos and Palencia Provinces (ROA 2015). The geopark includes 16 municipalities with a total of 13,076 inhabitants, a population density below 7 persons $/ \mathrm{km}^{2}$, which is characteristic of a depopulated region (Sacristán de Pablo 2012).

From the geological point of view, LLG is in the southern border of the Cantabrian Belt, at the southeast of the Palaeozoic Asturian Massif, and in the southwestern portion of the Basque Cantabrian Basin (Basconcillos Arce et al. 2005; Salazar Celis 2008). The geological heritage of the territory is mainly based on a Mesozoic sequence which records the evolution of the southwestern portion of the Basque Cantabrian Basin (IELIG 2018). Two other relevant geological features are the inverted relief, with plateaus as hanging synclines (Gómez et al. 2002), and karst landscape (ROA 2015).

The geoheritage inventory of Castilla and León Autonomous Community is not yet concluded. Nevertheless, five geological sites of LLG are in the Palencia geoheritage inventory, and four of them are included in the Castilla and Leon Natural Areas Network (Fernández-Martínez et al. 2010). In addition, there are three geosites of national relevance, eight with regional relevance, and three with provincial relevance for Burgos Province (Santos-González and MarcosReguero 2018). The geoheritage inventory undertaken by the management team of LLG is a list of 94 geological sites, subdivided into 12 types of geological interest (ROA 2015).

Castilla and León Autonomous Community has a Natural Heritage Law 4/2015, which establishes specific protection for geoheritage. In addition, this law establishes a Network of Natural Areas of Special Interest which includes geological and paleontological sites (BOCYL 2015).

The first idea to create this geopark started in 2004, followed by the establishment of the Association of the Las Loras Geological Reserve (ARGEOL), which is responsible for the general management of the project since 2005 (ROA 2015). Eleven years later, the UGGp application was sent to UNESCO in 2015, and LLG was recognized by UNESCO in 2017. 
Fig. 1 Data analysed in Las Loras and Comarca de Molina de Aragón-Alto Tajo UNESCO Global Geoparks

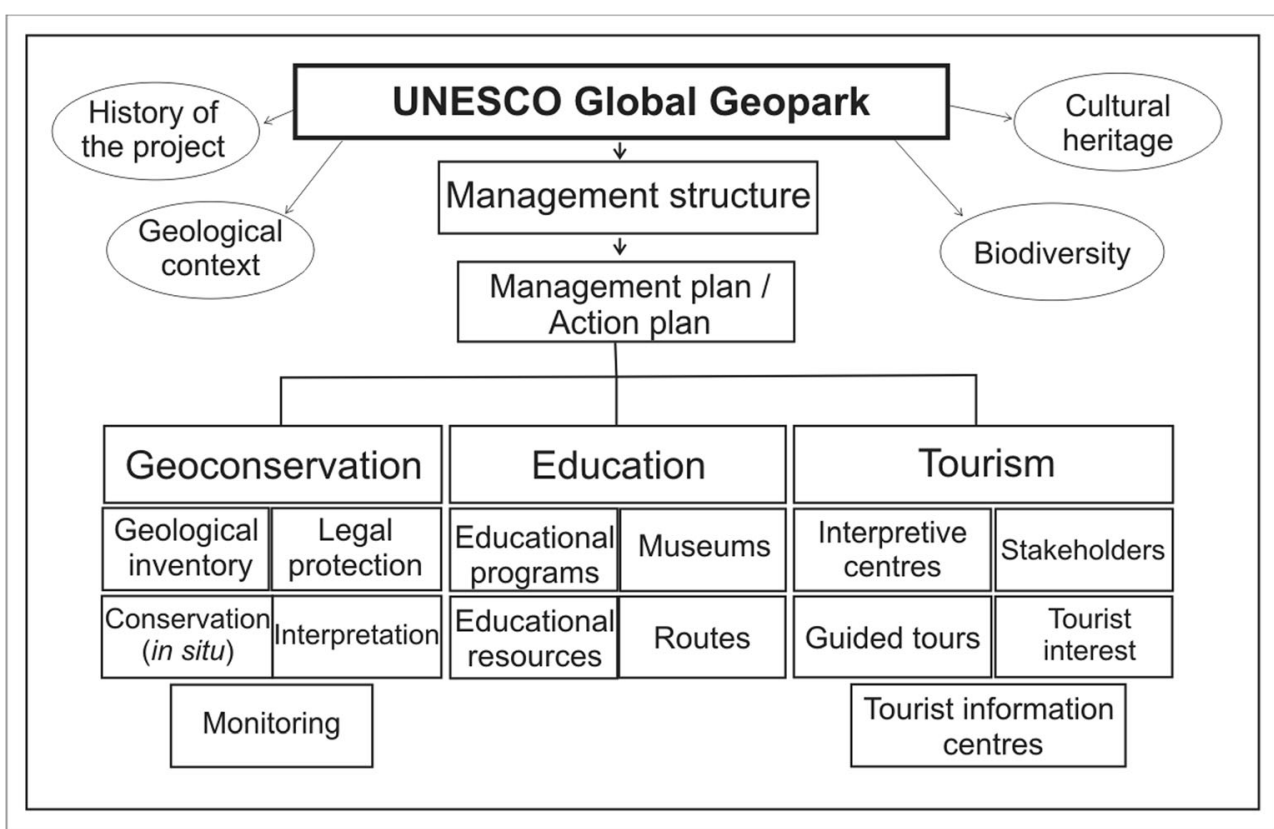

The management structure of the geopark is ARGEOL, founded by many local associations that represent the diversity of actors in the territory. This association is responsible for the project's legal support and leadership. The geopark administration is composed by an executive board, a scientific advisory committee, and a socioeconomic committee. Two geologists are the only full-time staff members for the geopark. The funding comes mainly from three sources: the Burgos and Palencia provincial administration with the highest amount; the local rural development group; and the regional government of the Autonomous Community, which provides other types of support, such as workers to maintain the trails and to clean the sites.

Up to now, the LLG does not have a complete management plan covering all the areas of action that are relevant for geopark. However, even if there is no management plan, the conservation, promotion, and monitoring of sites are developed in some specific sites. There are four interpretive geological itineraries, and one geological site monitoring at Cueva de los Franceses, a cave monitored by an engineering company.

The LLG offers several educational activities but there are no integrative programmes for schools, covering different education levels and subjects. However, there is an abundant variety of educational material adapted to these activities, including interpretive panels in some trails.

Regarding interpretive centres and museums, there are four facilities related to geodiversity and five related to cultural sites. The main touristic attractions in LLG are related with natural heritage (geomorphological features) and with cultural heritage (the Romanesque architecture) (ROA 2015).
In 2018, LLG received the GGN Best Practice Award for its geo-partners, especially the geo-bakery that produces bread in the shape of the local fossils, generating a special link between geoheritage and local products (GGN 2018).

\section{Comarca de Molina de Aragón-Alto Tajo UNESCO Global Geopark}

Comarca de Molina de Aragón-Alto Tajo UGGp (MATG) is located in the central Spain, in the Castilla-La Mancha Autonomous Community. The whole $4000 \mathrm{~km}^{2}$ is within the Province of Guadalajara (ROA 2012). The area of the MATG corresponds to the entire Molina de Aragón region, an administrative unit between the municipality and province levels, known as "Comarca" and referred historically as "Señorío de Molina", with 70 municipalities, 11,500 inhabitants, and 2.8 persons $/ \mathrm{km}^{2}$, which is indicative of a demographic desert (Martínez et al. 2011).

From the geological point of view, MATG is located in the Castillian Branch of the Iberian Range (Vera 2004). The geological heritage is based on important stratigraphic sections of the Silurian, Ordovician, Triassic, Jurassic, and Upper Cretaceous, together with the type locality for aragonite (calcium carbonate polymorphic mineral from Triassic, "Río Gallo" deposit near Molina de Aragón), the Global Standard Stratigraphic Section and Point (GSSP) for the ToarcianAalenian Boundary in the Fuentelsaz section, and important fossiliferous deposits for the Silurian and Jurassic (ROA 2012).

The geoheritage inventory of Castilla-La Mancha Autonomous Community is not concluded but MATG has a list of 62 geological sites that was prepared for the EGN 
application in 2012, in which $75 \%$ of these sites are located inside ATNP, a protected area included in the geopark territory. According to Carcavilla (2007), 125 geological sites were registered in the management plan of ATNP, together with geoconservation measures. Three sites of MATG have international relevance and are included in the IGME geosite database produced under the scope of the Global Geosites Project (SGGP 2018). The nature conservation Law 9/1999 of Castilla-La Mancha Autonomous Community addresses the protection of geological heritage through the establishment of natural monuments, and also includes significant geological elements in other categories of protection (Carcavilla et al. 2011).

The history of MATG is related with two pre-existing organizations: the ATNP, established in 2000 to protect the high value of geological elements, fauna, and flora (Carcavilla et al. 2011), and the Molina Museum created in 2002 that promotes activities about palaeontology, mineralogy, archaeology, and natural history (Martínez et al. 2011). Interpretive geological itineraries were created in 2006 to promote the ATNP geodiversity (Carcavilla 2006). Based on the idea that both organizations had common aims, the MATG Project was then created to promote a joint cooperation platform (Martínez et al. 2011). In 2014, the MATG was accepted as an EGN member and GGN member. In 2015, with the IGGP establishment, all GGN members were assimilated as UGGp.

The management structure of MATG is the Association of Friends of Molina de Aragón Museum (AAMM), with the support of an executive board and a scientific advisory committee (according to information provided by the MATG manager and president of the AAMM, Juan Manuel Monasterio, personal communication, 2017). However, in the MATG application to EGN, the management structure was a MolinaAlto Tajo Geopark Association (ROA 2012). The geopark has six full-time staff, and the funding comes from six different sources (regional, provincial, and municipal governments; two local development groups; and AAMM). The MATG does not have specific action plans, and the general management plan is incomplete.

In 2006, nine geological interpretative itineraries were open (Carcavilla 2007), and later, a geological guidebook was produced (Carcavilla et al. 2011). In the last years, due to the general drastic budget decrease after the economic crisis of 2008, many ATNP activities were interrupted, visitor centres were closed, and conservation, promotion, and maintenance actions were stopped. On the other hand, MATG has different financial sources, promoting concrete geoconservation actions according to temporary needs, but without specific strategies leading to action plans. One example is the Sierra de Aragoncillo, a geosite monitored by IGME and Complutense University of Madrid, in which the MATG encourages and supports the actions undertaken by the researchers (Díez-Herrero et al. 2017).
Regarding education, in 2018, the MATG started the exchange of high school students with the El Hierro UGGp. The Molina Museum promotes since 2011-2012 a school programme to introduce regional geology topics in the schools curriculum. They also promote field trips for different school educational levels, as well as teachers' training (ROA 2012). The educational material in the MATG comprises geological interpretive panels, tourist guides, geological material for fieldtrips, and books about the regional natural heritage. Additionally, there is some material adapted for people with disabilities, such as a viewpoint with an interpretive panel written in Braille, and wheelchair accessibility (Canesin et al. 2017).

The ATNP is the main touristic attraction in the geopark's territory. There are four interpretive centres and five museums, but surprisingly MATG is not promoted in the Molina de Aragón tourist centre, just in the Molina Museum. Moreover, there are annual thematic fairs organized by MATG, such as a gift fair, a handcraft fair, a truffle fair, and a hunting and fishing fair.

\section{Discussion}

UNESCO Global Geoparks are areas with geological heritage of international significance and aiming the sustainable development through social, environmental, and economic systems (UNESCO 2016). Therefore, it is necessary to know the main strategies and actions that must support any geopark management: geoconservation, education, and geotourism (Brilha 2018).

Our study is based on the comparison of how Las Loras and Comarca de Molina de Aragón-Alto Tajo UGGps are managed (Table 1). The LLG is a solid project with 13 years of development, located in two different provinces and recognized by UNESCO since 2017. On the other hand, the MATG is four times larger than LLG, is more recent, and is located in only one province. MATG is part of GGN since 2014.

\section{Geoconservation Strategies}

Geoconservation strategies must be applied in the management of all geodiversity elements with some notable value (Brilha 2016). The first step of this process is to know the territory in detail through systematic geological inventory and characterization of the value of the geological elements (Carcavilla 2014; Brilha 2016). Thus, systematic geological inventories are highly important in geoparks, considering that they are completely dependent on geological heritage, for their existence and recognition by UNESCO.

The absence of a systematic geological inventory in geoparks may contribute to a lack of knowledge about geological heritage that might be lost, and to an incorrect use of 
Table 1 Comparative analysis regarding management, geoconservation, education, and tourism activities in Las Loras and Comarca de Molina de Aragón-Alto Tajo UNESCO Global Geoparks

\begin{tabular}{|c|c|c|}
\hline & Las Loras Geopark & $\begin{array}{l}\text { Comarca de Molina de } \\
\text { Aragón-Alto Tajo Geopark }\end{array}$ \\
\hline Area & $950 \mathrm{~km}^{2}$ & $\sim 4000 \mathrm{~km}^{2}$ \\
\hline \multicolumn{3}{|l|}{ Management } \\
\hline Management structure and type & ARGEOL - participative & AAMM—centralized \\
\hline Number of full-time staff & 2 & 6 \\
\hline Strategic/action plan & Yes. Does not cover all areas of activities & No \\
\hline Management plan & No & Incomplete \\
\hline Number of funding sources & 3 & 6 \\
\hline Geopark with pre-existing infrastructure & No & Yes \\
\hline \multicolumn{3}{|l|}{ Geoconservation } \\
\hline Systematized geological inventory & No & No \\
\hline $\begin{array}{l}\text { Statutory protection of the autonomous } \\
\text { community }\end{array}$ & $\begin{array}{l}\text { Law } 4 / 2015 \text { of Castilla and León, } \\
\text { on natural heritage }\end{array}$ & $\begin{array}{l}\text { Law 9/1999 of Castilla-La Mancha, } \\
\text { on nature conservation }\end{array}$ \\
\hline Real effectiveness of the law for the geopark & No & Yes \\
\hline $\begin{array}{l}\text { Number of sites identified by the Global Geosites } \\
\text { Project }\end{array}$ & 0 & 3 \\
\hline Conservation (in situ) & No strategies & No strategies \\
\hline Promotion & No strategies & No strategies \\
\hline Infrastructure maintenance & No strategies & No strategies \\
\hline Geological site monitoring & $\begin{array}{l}\text { "Cueva de los franceses" } \\
\text { (not performed by LLG team) }\end{array}$ & $\begin{array}{l}\text { "Sierra de Aragoncillo" } \\
\text { (not performed by MATG team) }\end{array}$ \\
\hline Interpretation resources & $\begin{array}{l}\text { Panels with difficult geological language for general } \\
\text { public }\end{array}$ & Accessible to all types of public \\
\hline Scientific activities & Great incentive & Insufficient information \\
\hline \multicolumn{3}{|l|}{ Education } \\
\hline Educational programmes & No & No \\
\hline Exceptional educational activities & ERASMUS Plus Exchange Program & Geological Heritage Summer Course \\
\hline Educational resources & Adapted for many activities & Adapted for a few activities \\
\hline Number of interpretive routes & 4 & $\begin{array}{l}13 \text { ( } 3 \text { of them without } \\
\text { promotion/information) }\end{array}$ \\
\hline \multicolumn{3}{|l|}{ Tourism } \\
\hline Number of interpretive centres & 2 & 4 \\
\hline Number of museums & 7 & 5 \\
\hline Number of tourist information centres & 3 & 2 \\
\hline Main tourist interest & Romanesque architecture and geological sites & Alto Tajo National Park \\
\hline
\end{tabular}

geological sites. Other problems may arise, such as (a) lack of defined boundaries for each site; (b) non-integration of geological sites into the national geological frameworks that are defined in the Spanish national Law 42/2007; and (c) difficulty in identifying the site's value and the best infrastructure to support its potential use (touristic, educational, and/or scientific).

After the conclusion of a systematic geological inventory, including the quantitative assessment of scientific value, potential use, and risk of degradation, the management of geological sites is a fundamental step in any geoconservation process (Wimbledon et al. 2004; García-Cortés et al. 2012). However, when this management is not extended to all geological sites of a geopark in a comprehensive way, but just based on isolated actions, as it happens at LLG and MATG, it is only possible to do a partial evaluation of the effective results.

An UGGp is not a protected area category. Hence, geoparks must use the national statutory support to ensure the protection of the most important geosites (Brilha 2018). However, according to Crofts et al. (2015), the protected area procedures for conservation can be used as a basis for the management of geosites in geoparks. Both geoparks should apply national/regional statutory protection tools that are available for their territories in order to guarantee the geoheritage protection. 
As geoconservation is still considered and emergent geoscience (Henriques et al. 2011), technical terms are often used in different ways by different people, raising confusing meanings. Gray (2004) considers that geodiversity elements may present several types of values (scientific, cultural, aesthetic, intrinsic, and other ones) with different geographic significance (local, national, international). However, the UNESCO (2016) application forms consider the geodiversity value as being international, national, regional, or local. These confusing uses of terms were also verified in the LLG and MATG documentation.

\section{Management Structures}

The management structure is fundamental to ensure the success of a geopark. It must be well defined, organized under national policies, and well developed in order to accomplish all basic requirements of an UGGp (Carcavilla and García Cortés 2014).

The management structure of LLG-ARGEOL-is composed of several local associations and runs a participative management. In 2018, LLG updated the management structure with two new boards assisting the executive committee and the management team, respectively: an advisory board and a collaborative board. The first one is composed of a socioeconomic committee, a scientific committee, and a local development committee. The second one consists of partner companies, volunteer groups, universities, and other educational centres.

The MATG is managed by the Association of Friends of Molina de Aragón Museum (AAMM), with the same staff shared between the geopark and the Molina Museum. The president of the association is also the MATG manager, which develops a centralized management. Recently, after the fieldwork referred, MATG made available the information about three levels of management: the first level has the maximum external participation and is composed by the scientific and social committees; the second is the level of decision-making constituted by the executive committee; and the third level, represented by AAMM, is responsible for the implementation of the decisions taken by the executive committee and for the daily routines.

According to the UNESCO (2016) geopark concept, the ideal management type is a participative management, as the one at LLG, also known as bottom-up approach. This type of management allows more cooperation and participation of the community, spreading the knowledge, and inducing the local population to be proud of its territory. Additionally, the participative management allows the staff to be more connected and creative, with collective sense, working together with the community in benefit of the sustainable development of the territory. On the contrary, a centralized management is a structure with less proximity with local stakeholders and communities. At the MATG, there is an apparent difficulty in separating the assignments between the Molina Museum and the geopark. Even if the existence of partnerships between museums and geoparks is common, they should have different tasks and, ideally, they should be managed by different teams. Nevertheless, it is understandable that the lack of funding generates tight compromises.

It is important to have diverse expertise in the geopark staff, forming a team capable to create and implement broad strategies and actions. In particular, experts in geoconservation are needed to manage the geological heritage, which is a fundamental aspect of any geopark. Another important factor is a good permanent communication between the geopark staff and the local public authorities, which varies according to successive political mandates at the different administrative levels.

The importance of a management plan is to guide, organize, and coordinate all the geopark attributes, improving partnerships and developing new networks, to ensure that the geological heritage is properly managed and promoted for the present and future ERGO ( n.d.). Ferrari and Masè (2009), describing the Adamelo Brenta UGGp (Italy), state that the action plan has the purpose to follow the goals in different areas (conservation, research, and development), identifying, defining, and prioritizing actions and resource plans. On the absence of the mentioned plans, the actions are unsystematic and positive outcomes are more difficult to achieve and properly assess. Regarding these aspects, both LLG and MATG would benefit if an efficient planning was in place.

Another factor that contributes to the progress of the geopark is the pre-existence of an infrastructure that facilitates the development of activities and actions in the short-tomedium term. The MATG had the Molina Museum and a good infrastructure in the ATNP before the geopark creation. This situation has contributed to obtain more funding sources and full-time staff, when compared with LLG that had to start from the scratch (Table 1).

Lastly, under the management theme, it is extremely important that all actions and activities done in a geopark are recorded in a database, as this will support the geopark development analysis over time. The absence of a proper database in both geoparks has made the current research a major challenge and surely is also a disadvantage for the geopark staff when they have to produce reports and prepare the reevaluation dossier.

\section{Educational Strategies}

Environmental education and education for sustainability must drive the educational programmes and activities in a geopark (Catana et al. 2011). 
At LLG, there are different educational activities in the territory and nearby villages. During the UNESCO mission evaluation, local students made presentations of the Las Loras aspiring geopark to evaluators. This initiative allowed students to get contact with the evaluation process and gave the sense of belonging and appreciation of the local heritage to the local community. LLG also created an Erasmus Exchange Programme between teachers and students from local schools in four geoparks from Greece, France, Spain, and Portugal.

At MATG, every year some students from Molina de Aragón school visit the Molina Museum and an archaeological site, which could be an opportunity for the geopark team to introduce the geopark to these students. In addition, counselling programmes for schools should be promoted, introducing geological themes to schools and creating regular educational programmes and activities. In MATG there are many interpretive geological itineraries well promoted and with good infrastructure, namely inside ATNP. These trails could be used by the geopark staff for the teaching and promotion of local geoheritage.

The existence of multidisciplinary educational programmes for different school levels with the aim to convert the territory into a teaching laboratory could be a short-term task for both geoparks. The experience of the four Portuguese UGGps should be seen as a best-practice example for other geoparks (Catana and Rocha 2009; Catana 2012).

There is a great diversity of educational resources available at LLG, adapted according to their content and type of nonformal activities. Some examples of these resources are as follows: field book for students, material for teachers and tour guides in the training courses, and Las Loras educational guide, among others. Following the general principles of interpretation (Tilden 1977), some interpretive panels should have a geological language understandable by lay people and related to the expectations of the public, which usually do not have a deep knowledge on geosciences.

Regarding educational resources available at MATG, they are mostly associated with the ATNP and they were created before the geopark, a fact that probably boosted the application of the geopark. The interpretive panels and the geological guidebook of ATNP constitute a set of high-quality educational materials adapted to different types of visitors. It would be interesting to create specific educational material for other activities, such as the examples of Las Loras didactic guide and material for teachers and guides that have participated in training courses.

\section{Tourism Strategies}

Tourist information centres are an important and effective resource to make the geopark and its geoheritage known to residents and visitors (Macadam 2018; Newsome and Dowling 2018). The LLG presents detailed information and broad promotion of the geopark in tourist centres. The staff of these centres received training to introduce the concepts related with geoparks, and also to learn about the LLG's heritage and strategy. This effort still needs to be implemented at MATG.

During the field work in both geoparks, it was possible to join guided visits to museums, geosites, and interpretative trails. Considering that it is important to explain to visitors what is a geopark, MATG would benefit of an increase of the geopark promotion. Similarly, LLG could provide more information about geological trails and routes.

The collection of data about visitors and its statistical treatment (visitor management) allows to establish the profile of a typical visitor, which is an important information for geopark managers (Newsome et al. 2012). This is something that should be promoted in the two case-studies under analysis, contributing to a better definition of working strategies.

Finally, the establishment of a solid network of geopark partners related with geotouristic activities is also considered a fundamental aspect to develop the touristic attractiveness of the geopark, with clear benefits for all (Zouros 2004; UNESCO 2016; Newsome and Dowling 2018).

\section{Conclusion}

This research was developed in 2016-2017 and all the data presented here were obtained during that period. This means that the present situation in both geoparks might be slightly different in certain aspects of the research. Despite the constrains that have been detected in both geoparks, it should be underlined that the geopark concept is not compatible with short-term results and that is a continuous process of improvement.

In the last 19 years, geoparks have become more well known, expanding from just four geoparks in four countries in 2000 to the current 147 geoparks in 41 countries (Zouros 2004; Henriques and Brilha 2017; Brilha 2018; UNESCO 2018). This tendency is especially meaningful after the creation of the International Geoscience and Geoparks Programme (IGGP) in 2015, which has reinforced the image and the importance of these territories.

Spain is the first country with the highest number of UGGps in Europe, and the second (after China) in the world. Among other possible factors, this leadership of Spain might be explained by the existence of a specific Geoheritage Department in the Geological Survey of Spain with a dedicated team of experts, the funding support from rural development groups, the existence of geoconservation dedicated laws, the success of many geoheritage promotion activities addressed to the general public, and, of course, the commitment of all the people that are working seriously in geoparks since the year 2000 . 
The comparison done in this work between LLG and MATG has proven that there are no significant differences between the data collected at both geoparks, although they are in different stages of development. The main divergent points are (a) the existence or not of infrastructure prior to the creation of the aspiring geopark, (b) the scientific relevance of geological heritage, and (c) the type of management.

With our research, we are able to confirm that there are some important points that need to be seriously considered by geoparks and aspiring geoparks.

Regarding management, it is important to assure (a) the existence of management and action plans, (b) the implementation of a participative management that involves the community in actions and activities, (c) a well-coordinated team following an annual planning previously approved, and (d) the setup of a specific database to record data about all actions and activities develop in the geopark.

Considering that geoconservation should be one of the most important tasks in a geopark, it is highly advisable (a) to have a systematic inventory of geological sites which includes the assessment of values, potential uses and risk of degradation, (b) to apply statutory regulations to protect the most important sites, (c) to guarantee that the geopark staff includes an expert on geoconservation, (d) to apply the concepts and principles of geoconservation that are generally accepted worldwide.

Together with geoconservation, education and geotourism are the two other pillars that complement an integrated management of geoparks. Therefore, it is necessary (a) to implement educational programmes adapted to different school levels, (b) to diversify the type of educational activities and educational materials, (c) to establish an efficient workflow with the local tourism offices, which are important agents for the geopark diffusion, and (d) to implement practical links with local businesses in order to develop innovative products and to improve the local economy, simultaneously promoting the geopark.

In spite of the fact that some of these recommendations are already included in UGGp guidelines, this work has demonstrated that they are not always followed by geoparks, originating a decrease on the effectiveness of the work promoted by these geoparks. The re-evaluation process that UNESCO promotes in each 4 years is an important asset of the IGGP, as a quality control of the work that is being done in geoparks. The more rigorous this re-evaluation process is, the better the management structure of any geopark will work in order to keep the so desired UNESCO label.

Acknowledgements The authors would like to acknowledge the Geological Survey of Spain (IGME) for assistance and support. We also thank Las Loras Geopark and Comarca de Molina de Aragón-Alto Tajo Geopark for their collaboration with this research and with the field logistics. Finally, we thank to the organizers of the IX International ProGEO Symposium, Chęciny, Poland, 2018, for the opportunity to write this paper; Dr. Heloísa S. Canesin for helping with the English writing; and the reviewers that helped to improve the quality of the manuscript.

Funding Information Part of this research was funded by the Erasmus Plus Programme and by the European Union through the European Regional Development Fund, based on COMPETE 2020, project ICT (UID/GEO/04683/2019) with reference POCI-01-0145-FEDER-007690 and national funds provided by Fundação para a Ciência e Tecnologia.

\section{References}

Basconcillos Arce J, Gonzáles PLG, Fabián JAS (2005) Reserva Geológica Las Loras, 1, Estudio para la creación de una reserva geológica en Las Loras (Burgos- Palencia)

BOCYL (2015) Boletín Oficial de Castilla y León. Ley 4/2015, de 24 de marzo, del Patrimonio Natural de Castilla y León 61:23956-24016

Brilha J (2016) Inventory and quantitative assessment of geosites and geodiversity sites: a review. Geoheritage 8:119-134

Brilha J (2018) Geoheritage and geoparks. In: Reynard E, Brilha J (eds) Geoheritage: assessment, protection and management. Elsevier, Amsterdam, pp 323-335

Canesin T (2017) Análise comparativa da implementação de desenvolvimento dos Geoparques Mundiais da UNESCO Las Loras e Comarca de Molina de Aragón-Alto Tajo (Espanha) e propostas de gestão. Dissertation, University of Minho

Canesin T, Brilha J, Díaz-Martínez E (2017) UNESCO Global Geoparks: towards the inclusion of people with disabilities. In: Lima EA, Nunes JC, Meirinho P, Machado M (eds) Abstract book 14th European Geoparks Conference 'Geoparks: pathways of sustainable tourism for development'. 7-9 September 2017. Ponta Delgada, Azores. Portugal. Azores UNESCO Global Geopark, Ponta Delgada, $\mathrm{p} 111$

Carcavilla L (2006) Interpretación de la geologia: las geo-rutas del Parque Natural del Alto Tajo. Tierra y Tecnología 29:11-16

Carcavilla L (2007) La divulgación de la geología en espacios protegidos: las geo-rutas del Parque Natural Alto Tajo (Guadalajara). Enseñanza de las Ciencias de la Tierra 15:65-76

Carcavilla L (2014) Guía práctica para entender el patrimonio geológico. Enseñanza de las Ciencias de la Tierra 22:5-18

Carcavilla L, García Cortés A (2014) Geoparques. Significado y Funcionamiento. Instituto Geológico y Minero de España, Ministerio de Economia y Competitividad http://www.igme.es/ patrimonio/Geoparques-IGME2014-1.pdf. Accessed 25 November 2016

Carcavilla L, Ruiz R, Rodríguez E (2011) Guía Geológica del Parque Natural del Alto Tajo. Instituto Geológico y Minero de España, Madrid

Catana MM (2012) An overview of the five years of the Naturtejo Geopark (Portugal) educational programmes and the next challenges. In: Sá AA, Rocha D, Paz A, Correia V (eds) Proceedings of the 11th European Geoparks Conference. 19-21 September 2012. Associação Geoparque Arouca, Arouca, Portugal, pp 73-74

Catana MM, Rocha D (2009) The role of the educational programs on tourism development of Naturtejo and Arouca Geoparks. In: Neto de Carvalho C, Rodrigues J (eds) Proceedings of the 8th European Geoparks Conference. 14-16 September 2009. Geopark Naturtejo, Idanha-a-Nova, Portugal, pp 61-65

Catana MM, Carvalho CN, Canilho S (2011) A GEONATUR escola do Geopark Naturtejo: programas educativos em geociências e para a sustentabilidade. Livro de Resumos Conferência GEOescolas: Novas práticas no ensino em Geociências. 5-6 November 2011, Idanha-a-Nova, Portugal. Geopark Naturtejo, Idanha-a-Nova, Portugal, pp 30-31 
Crofts R, Gordon JE, Santucci VL (2015) Geoconservation in protected areas. In: Worboys GL, Lockwood M, Kothari A, Feary S, Pulsford I (eds) Protected area governance and management. ANU Press, Canberra, pp 531-568

Díaz-Martínez E, Salazar A, García-Cortés A (2014) El patrimonio geológico en España. Enseñanza de las Ciencias de La Tierra 22: 25-37

Díez-Herrero A, Luengo J, Hernández M, Carcavilla L, Sopeña A, Sánchez-Moya Y, Moratalla J, Baeza E, García-Cortés A (2017) Propuesta de monitorización instrumental para la geoconservación del LIG "Icnitas de reptiles triásicos" en el Geoparque de la Comarca de Molina-Alto Tajo (Guadalajara). In: Carcavilla L, Duque-Macías J, Giménez J, Hilario A, Monge-Ganuzas M, Vegas J, Rodríguez A (eds) Patrimonio geológico, gestionando la parte abiótica del patrimonio natural. Cuadernos del Museo Geominero, Instituto Geológico y Minero de España, Madrid, 21:155-160

ERGO English Riviera Geopark Organization (n.d.) The English Riviera Geopark Management Plan. http://www.englishrivierageopark.org. uk/documents/geoparkmanplan.pdf. Accessed June 2016

Fernández-Martínez E, Fuertes-Gutiérrez I, González-Gutiérrez RB, Redondo Vega JM, Alonso Herrero E (2010) Lugares de Interés Geológico en la provincia de Palencia (noroeste de España): un inventario y varios casos de estudio. Cuadernos del Museo Geominero, Instituto Geológico y Minero de España 12:91-107

Ferrari C, Masè V (2009) Action Plan of the Adamello Brenta Geopark. In: Neto de Carvalho C, Rodrigues J (eds) New Challenges with Geoturism. Proceedings of the 8th European Geoparks Conference. 14-16 September 2009. Idanha-a-Nova, Portugal. Geopark Naturtejo, Idanha-a-Nova, Portugal, pp 78-79

García-Cortés A, Vegas J, Carcavilla L, Díaz-Martínez E (2012) Un sistema de indicadores para la evaluación y seguimento del estado de conservación del patrimônio geológico. Geo-Temas 13:12721275

GGN (2018) Global Geoparks Network. International Association on Geoparks. http://globalgeoparksnetwork.org. Accessed June 2019

Gómez M, Vergés J, Riaza C (2002) Inversion tectonics of the northern margin of the Basque Cantabrian Basin. Bulletin de la Société géologique de France 173(5):449-459

Gray M (2004) Geodiversity: valuing and conserving abiotic nature. John Wiley and Sons, Chichester

Henriques MH, Brilha J (2017) UNESCO Global Geoparks: a strategy towards global understanding and sustainability. Episodes 40(4): 349-355

Henriques MH, Reis RP, Brilha J, Mora T (2011) Geoconservation as an emerging geoscience. Geoheritage 3:117-128

IELIG (2018) Inventário Español de Lugares de Interés Geológico. Instituto Geológico y Minero de España. http://info.igme.es/ielig/. Accessed June 2018

Macadam J (2018) Geoheritage: getting the message across. What message and to whom? In: Reynard E, Brilha J (eds) Geoheritage: assessment, protection and management. Elsevier, Amsterdam, pp 267-288
Martínez JA, Carcavilla L, Monasterio JM, Vela A (2011) El Proyecto del Geoparque de la Comarca de Molina y el Alto Tajo. In: FernándezMartínez E, Luis RC (eds) Avances y retos en la conservación del Patrimonio Geológico em España. Actas de la IX Reunión Nacional de la Comisión del Patrimonio Geológico (Sociedad Geológica de España). 14-18 Junio 2011, León, España. Instituto Geológico y Minero de España, Madrid, pp 156-161

McKeever PJ (2015) International geoscience and geoparks programme. In: Saari K, Saarinen J, Saastamoinen M (eds) Responsible use of natural and cultural heritage. Proceedings of the 13th Geoparks Conference. 3-6 September 2015. Geopark Rokua, Finland, p 16

Newsome D, Dowling R (2018) Geoheritage and geotourism. In: Reynard E, Brilha J (eds) Geoheritage: assessment, protection and management. Elsevier, Amsterdam, pp 305-322

Newsome D, Dowling R, Leung YF (2012) The nature and management of geotourism: a case study of two established iconic geotourism destinations. Tour Manag Perspect 2:19-27

ROA (2012) Report of the Official Application of Molina and Alto Tajo Geopark. http://www.geoparquemolina.es/web/guest/applicationgeopark-dossier. Accessed October 2018

ROA (2015) Report of the Official Application of Las Loras Geopark. https://geoparquelasloras.es/index.php/documentos/. Accessed October 2018

Sacristán de Pablo A (2012) Reserva Geológica de Las Loras: Diagnóstico y propuestas para la creación del Geoparque Las Loras. Dissertation, Complutense University of Madrid

Salazar Celis HP (2008) Caminando por Las Loras. Asociación ADECOCamino de Santiago, Burgos

Santos-González J, Marcos-Reguero A (2018) Applying the geological heritage in land management: cartography and management proposals of geosites in Burgos Province (Spain). Geoheritage 11(2): 485-500

SGGP (2018) Global Geosites Project. http://www.igme.es/patrimonio/ GlobalGeosites.htm\#lugar. Accessed May 2018

Tilden F (1977) Interpreting our heritage. 3rd edn. The University of North Carolina Press

UNESCO (2016) UNESCO Global Geoparks, Celebrating Earth heritage, sustaining local communities. http://www.globalgeopark.org/ UploadFiles/2016_2_16/UNESCO\%20Global\%20Geopark\% 20Brochure.pdf. Accessed November 2016

UNESCO (2018) Earth Science. UNESCO Global Geoparks. http:// www.unesco.org/new/en/natural-sciences/environment/earthsciences/unesco-global-geoparks/. Accessed September 2018

Vera JA (2004) Geologia de España. SGE-IGME, Madrid

Wimbledon WAP, Bernard AF, Peterken AG (2004) Geosite management - a widely applicable, practical approach. In: Parkes MA (ed) Natural and cultural landscapes - the geological foundation. Royal Irish Academy, Dublin, pp 187-192

Zouros NC (2004) The European geoparks network: geological heritage protection and local development. Episodes 27(3):165-171 